Modern Asian Studies 55, 4 (202I) pp. II85-I226. (C) The Author(s), 2020. Published by Cambridge University Press. This is an Open Access article, distributed under the terms of the Creative Commons Attribution-NonCommercial-NoDerivatives licence (http:// creativecommons.org/licenses/by-nc-nd/4.o/), which permits non-commercial re-use, distribution, and reproduction in any medium, provided the original work is unaltered and is properly cited. The written permission of Cambridge University Press must be obtained for commercial re-use or in order to create a derivative work.

doi:Io.IoI7/Soo26749X20000256 First published online i6 November 2020

\title{
To Be or Not To Be ... a Global Citizen: Three doctors, three empires, and one subcontinent*
}

\section{MARGRET FRENZ (iD}

\author{
University of Stuttgart \\ Email:margret.frenz@hi.uni-stuttgart.de
}

\begin{abstract}
This article investigates the circular intra- and transimperial movements of medical experts from colonial India in three imperial settings. The analysis of the trajectories of José Camillo Lisboa, Paramananda Mariadassou, and Mary Poonen Lukose highlights, first, how crucial freedom of movement - not only between parts of the same empire, but also across empire borders and between their metropoles as well as their colonies - was for individuals; secondly, how questions of citizenship, the recognition of degrees and certificates, and notions of gender, race, class, and place of origin played a role in enabling or preventing Indians living in Portuguese, French, or British India from studying or working elsewhere; and thirdly, how this in turn had an effect on their potential social mobility, which depended on the historical contingency of time and place, and the opportunities and limitations in these contexts. The article argues that through their chosen careers and their sociopolitical activities they expanded conventional notions of citizenship and lived as global citizens.
\end{abstract}

* Acknowledgements: I am particularly grateful to John Darwin, Festo Mkenda, Claire Phillips, Gopinath Ravindran, and $M A S$ s anonymous referees for their comments and suggestions. Earlier versions of this article were presented during my fellowship at the Institut d'Études Avancées de Nantes and at one of my Historikertag sections. My sincere thanks go to staff members at the consulted libraries and archives across India, Portugal, France, the United Kingdom, and Germany for their generous help and support. 


\section{Introduction}

Studies abound on how European colonial powers influenced and shaped the regions of India they colonized. Some also include the relationship between the metropolis and the colony. Rarely, however, do they take into account comparative perspectives of how Danish, Dutch, Portuguese, French, and British regulations allowed or hindered exchange or movement between the variously governed many-not one! - colonial Indias. ${ }^{1}$ Thus, much research and analysis have gone into understanding and interpreting intra-imperial relationships, whereas transimperial connections and social, economic, political, and cultural joint ventures across empire borders have received less attention. Many Indians, though, continued to move across the subcontinent, despite regulations that channelled, and sometimes restricted, their movements between different regions controlled by the Portuguese, French, or British in the nineteenth and twentieth centuries. $^{2}$ Movement within the Indian subcontinent remained significant, despite the tendency of the colonial states to emphasize the links between the metropolis and the colony, and the barriers being established between Portuguese, French, and British territories and the semi-autonomous princely states of the subcontinent.

Analysing the trajectories of individuals and families, I argue, highlights how vital personal, professional, and geopolitical entanglements (dis-) connecting Portuguese, French, British, and princely India were, despite the often-cited competition and rivalry between the European powers striving for domination. Transformations of interdependencies and impediments over time are reflected in the ways in which state policies and measures impacted on people's lives. My interest is in examining

${ }^{1}$ One of the few exceptions is B. Moore (ed.), Colonial Empires Compared. Britain and the Netherlands, 1750-1850, Ashgate, Aldershot, 2003. A more general, chronological overview of empires is provided by J. Burbank and F. Cooper, Empires in World History: Power and the Politics of Difference, Princeton University Press, Princeton, 2010, which also includes notes on empires active on the Indian subcontinent. Recent comparative perspectives have included work on empires in different world regions, such as M. B. Jerónimo and A. C. Pinto (eds), The Ends of European Colonial Empires: Cases and Comparisons, Palgrave Macmillan, Basingstoke, 2015; R. Gardella and J. Perry, Classical Roman and Chinese Empires Compared: Parallel Worlds, Routledge, London, 2018. Sanjay Subrahmanyam writes of the many Asias: S. Subrahmanyam, 'One Asia, or Many?', Modern Asian Studies, vol. 50, no. I, 2016, pp. 5-43.

${ }^{2}$ See Subrahmanyam, 'One Asia, or Many?', pp. 4I and 34, where he emphasizes that 'Not everything was connected, and not all of the time.' 
how individuals were able to move with ease along connective arteries and/or how they negotiated restrictions that threatened their aspirations in life. To what extent were their experiences of 'sailing through' or being impeded related to questions of gender, race, class, and caste? What actions did they take to circumvent or overcome hurdles in their paths? By exploring the intersections of empire, profession, and citizenship, I reflect on the opportunities and challenges encountered by medically trained Indians across three imperial settings on the subcontinent in the nineteenth and twentieth centuries. What unifies their trajectories over time and space is their ambiguous position in imperial societies as neither entirely privileged nor entirely marginalized. Rather, I contend, they were part of a subaltern elite, like Indian lawyers, engineers, or scribes, who had access to a certain range of benefits such as education, but only to some extent and only up to a certain point. ${ }^{3}$ They were frequently quite firmly 'shown their place' when it came to specific positions or promotions. Nevertheless, many of them stood their ground professionally and stretched confines imposed by colonial governments through enacting citizenship in creative ways.

This article investigates the circular intra- and transimperial movements of three individuals hailing from different parts of the subcontinent. All three desired to study and practise medicine, and they shared a passion for their profession, though they did so in different spaces at different times. They also shared an 'affirmative articulation of public subjectivity' ${ }^{4}$ through their sociopolitical activities. The analysis of their trajectories sheds light, first, on how freedom of movement was crucial for aspiring individuals - not only between parts of one and the same empire, but also across empire borders and between their metropoles as well as their colonies; secondly, how questions of citizenship, the recognition of degrees and certificates, and issues of race and origin played a role in enabling or preventing Indians living in Portuguese, French, or British India from studying or working in the locality of their choice; thirdly, how this in turn had an effect on their ability to practise medicine, on their potential social mobility, and, finally, on how they enacted citizenship as sociopolitical pursuit. All of these factors were interrelated. They depended on the historical contingency

\footnotetext{
${ }^{3}$ For a discussion of the concept of subaltern elites, see M. Frenz, Community, Memory, and Migration in a Globalizing World. The Goan Experience, c. I89o-1980, Oxford University Press, New Delhi, 2014, esp. pp. IO-I5.

${ }^{4}$ R. Asen, 'A Discourse Theory of Citizenship', Quarterly Journal of Speech, vol. 9o, no. 2, pp. I89-2II, p. I92.
} 
of time and place as well as the opportunities and limitations in theseintersecting - local, regional, and global contexts.

The comparative setting of this article shows that processes of professionalization in the colonies worked in similar ways across empires, even though details and individual trajectories might have differed significantly. In the nineteenth and twentieth centuries, such processes of professionalization occurred across imperial boundaries and led to increasingly standardized training in the professions, including engineering, the law, and medicine. ${ }^{5}$ Professionals were supposed to have absorbed whatever they needed to know about their métier, to be autonomous, and to take the idea of service seriously. ${ }^{6}$ In British India and the princely states, debates on the medical profession in the nineteenth and twentieth centuries were characterized by controversies as to whether so-called Western, allopathic or local, indigenous systems of medicine should be followed, what kind of educational institutions should be established that would provide recognized qualifications, and how the Indian Medical Service should be staffed, among other questions. $^{7}$ Indian doctors migrated — whether for education or work or to improve their social standing - to many locations; the literature exploring this phenomenon broadly agrees that the recognition of qualifications was, and still is, a major issue, and that Indian doctors largely work in the lowest-status specialisms and locations. ${ }^{8}$ Their movements are mentioned in several studies investigating Indian

\footnotetext{
${ }^{5}$ See, for instance, A. Ramnath, The Birth of an Indian Profession: Engineers, Industry, and the State 1900-47, Oxford University Press, New Delhi, 2017; N. Chatterjee, 'Law, Culture and History: Amir Ali's Interpretation of Islamic Law', in Legal Histories of the British Empire: Laws, Engagements and Legacies, S. Dorsett and J. McLaren (eds), Routledge, Abingdon, 20I4, pp. 45-59.

${ }^{6}$ See, for instance, J. Goldstein, 'Foucault among the Sociologists: The "Disciplines" and the History of the Professions', History and Theory, vol. 23, no. 2, I984, pp. 170-192.

${ }^{7}$ B. Pati and M. Harrison (eds), Health, Medicine and Empire: Perspectives on Colonial India, Orient Longman, Hyderabad, 2006; R. Jeffery, 'Recognizing India's Doctors: The Institutionalization of Medical Dependency, I918-39', Modern Asian Studies, vol. I3, no. 2, 1979, pp. 30I-326; M. Ramanna, Western Medicine and Public Health in Colonial Bombay 1845-I895, Orient Longman, Hyderabad, 2002; S. Sehrawat, Colonial Medical Care in North India: Gender, State, and Society c. I840-1920, Oxford University Press, New Delhi, 2013.

${ }^{8}$ See, for instance, J. M. Simpson, Migrant Architects of the NHS. South Asian Doctors and the Reinvention of British General Practice (I940s-1980s), Manchester University Press, Manchester, 2018; A. Esmail, 'Asian Doctors in the NHS: Service and Betrayal', British Fournal of General Practice, vol. 57, no. 543, 2007, pp. 827-834; J. Bornat, L. Henry and P. Raghuram, 'The Making of Careers, the Making of a Discipline: Luck and Chance in Migrant Careers in Geriatric Medicine', Journal of Vocational Behavior, vol. 78, no. 3, 201 I, pp. 342-350.
} 
migration to Great Britain in a more general context. ${ }^{9}$ In the French empire, discourses revolved around similar topics, including which local treatments might be adopted as they were perceived as 'appropriate', who could practise where based on which part of the empire they had earned their qualification, and who could be employed within the French medical services in the colonies. ${ }^{10}$ Again, topics of debate ranged from designing an overarching medical system for the empire to questions of which medical treatments would be beneficial. Laws passed by the Portuguese government included the objective to found medical schools in all parts of the empire. These would be connected to each other through a multi-tiered order based on qualifications, race, and place of origin. ${ }^{11}$

Undertaking research across three empires and their territories requires time and the knowledge of diverse archival and documentation structures that produced sources in several languages. Records written in Portuguese, French, Malayalam, Tamil, and English investigated for this article are located in multiple archives in India, Portugal, France, and Great Britain. They include, among others, government publications, institutional reports, newspapers, and journals. Even if 'official' documents and papers were comparatively easily accessible, private papers or grey literature were hard to find, and often chanced upon. It has been a challenge to find sources that reflect the individuals' voices, as very little original documentation of and by the individuals engaged with here has survived or is attainable. None of the three individuals left private papers in publicly accessible repositories: in one case, no trace of such papers was found; the second individual's notes are most probably held by descendants; and in the third case, redacted

${ }^{9}$ The classic is R. Visram, Ayahs, Lascars and Princes: The Story of Indians in Britain I70o1947, Pluto Press, London, 1986, followed by numerous studies on Indians in Britain, too numerous to be listed here.

${ }^{10}$ See, for instance, several essays in E. Longuenesse (ed.), Santé, médecine et société dans le monde Arabe, Éditions L’Harmattan, Paris, I995; A. M. Moulin, Le médecin du prince: Voyage à travers les cultures, Odile Jacob, Paris, 20ı; E. Jennings, Curing the Colonizers: Hydrotherapy, Climatology, and French Colonial Spas, Duke University Press, Durham and London, 2006 shows the appropriation of 'suitable' treatments practised in Réunion into methods of 'Western' medical concepts; and L. Monnais, 'Le Dr Nguyễn Văn Luyện et ses confrères: La médecine privée dans le Viêt Nam colonial', Moussons, vol. I5, 20Io, pp. 75-95.

${ }^{11}$ C. Bastos, 'Medicina, império e processos locais em Goa, século XIX', Análise Social, vol. 42, no. 182, 2007, pp. 99-122; F. da Silva Gracias, Health and Hygiene in Colonial Goa I5IO-I96I, Concept Publishing Company, New Delhi, I994. 
correspondence and diary entries have recently been published in an edited volume. ${ }^{12}$ The fragmentary and fractured nature of the records demand the historian's expertise in reading against the grain to tease out potential perspectives of individuals - or, in the words of Ann Laura Stoler, to recognize 'the distance between those normative, imposed categories of social difference that so contrast with the more mobile social and intimate relations in which people lived'. ${ }^{13}$ Thus, my methodological approach combines structural, analytical - or top down - and experiential, individual - or bottom up - perspectives. Historical documents have been analysed along the methods of historical critical enquiry, ${ }^{14}$ in particular, through triangulating and cross-examining records of different origin and nature.

\section{Dramatis personae}

The three individuals introduced in this part of the article moved across both colonial and metropolitan territories of European empires to undergo training in the field of medicine or to take up further studies. Sometimes, they stayed on for a while after completing their degrees or went on the move again. They all came back to India, either returning to their place of origin or moving between different locations in India.

\section{'A labour of love': Fosé Camillo Lisboa}

José Camillo Lisboa, born in I823, was a medical expert from Goa, who settled in Bombay. Having identified and described over a hundred plants that were used by the local population during the famine in the mid-I87os, Dr José Camillo Lisboa received high level Portuguese, British, and French honours. For instance, he was elected to the syndicate of the University of Bombay and received a gold medal from the Académie internationale de géographie botanique for his services to and

${ }^{12}$ M. Poonen Lukose, 'My 86 Years from 1886: A Random Look Backwards', in Trailblazer: The Legendary Life and Times of Dr Mary Poonen Lukose, Surgeon General of Travancore, L. Chandran (ed.), Manorama Books, Kottayam, 2019, pp. 15-53.

${ }^{13}$ L. A. Stoler, Along the Archival Grain: Epistemic Anxieties and Colonial Common Sense, Princeton University Press, Princeton and Oxford, 2009, p. 32.

${ }^{14}$ J. Rüsen, Grundzüge einer Historik, 3 vols, Vandenhoeck and Ruprecht, Göttingen, I983-1989. 
promotion of botany in India. ${ }^{15}$ He was a member of the Royal Academy of Sciences in Lisbon, the Geographical and Medical Societies in Lisbon, the Linnean Society in London, as well as the Académie internationale de géographie botanique in Paris. ${ }^{16}$

Lisboa taught at Grant Medical College Bombay for a few years and then focused on his own private clinic in the city. He also regularly assisted doctors at the Jamsetjee Jejeebhoy Hospital Bombay in the operating theatre. ${ }^{17}$ Leprosy was one of Lisboa's main medical research interests, and he presented the results of his work on leprosy at the Grant Medical College Society. Besides his medical career, Lisboa's passion was the study of plants, particularly grasses, two of which were named after him. ${ }^{18}$ One of those was first described by his wife Julia Rodrigues e Lisboa, who reported having assisted her husband in analysing and dissecting plants, and to having named the newly discovered grass. ${ }^{19}$ She might also have helped him to compile the List

${ }^{15}$ Anon., 'The Late Dr. J. C. Lisboa', The Lancet, i9 June i897, p. I7ı9; A. M. da Costa, Dicionário de Literatura Goesa, 3 vols, Instituto Cultural de Macau and Fundação Oriente, Macau, I997, Vol. 2, p. I93; T. Albuquerque, Goan Pioneers in Bombay, Goar556 and Broadway Publishing House, Goa, 2012, p. 90.

${ }^{16}$ Anon., 'Obituary Notices: Don José Camillo Lisboa', in Proceedings of the Linnean Society of London, Ioth Session, from November 1897 to June 1898, Taylor and Francis, London, I898, p. 4I. Lisboa was elected to the Society in I888, withdrew in I893, and was again elected in 1894 .

${ }^{17}$ M. V. de Abreu (ed.), Noção de alguns filhos distinctos da India Portugueza que se illustraram fora da patria, Nova Goa, Imprensa Nacional, I874, p. 28.

${ }^{18}$ Tripogen lisboae and andropogon odoratus lisboae.

${ }^{19}$ Mrs. J. C. Lisboa, 'Short Notes on the Odiferous Grasses (Andropogons) of India and Ceylon, with a Description of a Supposed New Species', Fournal of the Bombay Natural History Society, vol. 2, no. 4, I889, pp. II8-I24, I23, I24. Her second article lists the odiferous grasses of India and documents the discussion that ensued after her first article on the new species: Mrs. J. C. Lisboa, 'List of the Odiferous Grasses in India, with a Description of a New Species of Andropogon', Fournal of the Bombay Natural History Society, vol. 6, no. I, I891, pp. 64-7r. Julia Rodriges e Lisboa $(1840-1926)$ is one of the few women in the nineteenth century to write in the journal; I found only one other female authorJ. B. Hart - who published her findings in the journal's volumes between 1886 and I9oo, also under her husband's name 'Mrs. W. E. Hart'. See also M. R. S. Creese and T. M. Cresse, Ladies in the Laboratory II. West European Women in Science, I80o-I90o: A Survey of their Contributions to Research, The Scarecrow Press, Lanham et al., 2004, pp. $44^{-45}$. It is remarkable that Julia Lisboa presented both her papers at the society's meetings in 1889 and I89I, although she is not listed as a member: 'Mrs. J. C. Lisboa then read extracts from a paper which she has written for the Society's Journal, containing a complete account of the odoriferous [sic] grasses of India. Mrs. Lisboa also placed before the meeting a large collection of these grasses together with a description 
of Grasses in Bombay and their Uses. ${ }^{20}$ Lisboa published his botanical research results regularly in the Fournal of the Natural History Society of Bombay, of which he was an elected member from 1886. ${ }^{21}$ Some of his work appeared in journals of the Bombay branch of the Royal Asiatic Society and in overarching surveys such as the volume on botany of the Gazetteer of Bombay. ${ }^{22}$ In the 1880 s and I8gos, Lisboa maintained regular correspondence with botanists throughout the empire, especially at the Royal Botanic Gardens at Calcutta and at Kew. Mostly, the letters reflect discussions about certain plants, of which Lisboa sent specimens and drawings across the oceans every now and then to enable a more thorough debate between botanist colleagues. ${ }^{23} \mathrm{He}$ did not live to see his list of Bombay grasses published as a standalone book-it appeared shortly after his death in May $1897 .^{24}$

In addition to his professional life and his interest in botany, Lisboa published articles in the weekly $A$ abhelo de Bombaim, which featured political, literary, and economic essays. It seems he wrote in favour of the Portuguese imperial government and stood up for the interests of his fellow Goans in Bombay. ${ }^{25}$ His philanthropic activities included building a chapel and a school in his ancestral village, Assagao in Goa, and endowing prizes for students who achieved excellent grades. ${ }^{26}$

of a new species of Andropogon hitherto inedited', in Anon., 'Proceedings', Fournal of the Bombay Natural History Society, vol. 6, no. I, I89I, p. I27.

${ }^{20}$ J. C. Lisboa, List of Bombay Grasses and their Uses, Government Central Press, Bombay, I896.

${ }^{21}$ Fournal of the Bombay Natural History Society, vol. I, no. I, I886, p. 88.

${ }^{22}$ da Costa, Dicionário de Literatura Goesa, pp. I92-I94; J. C. Lisboa, 'Useful Plants of the Bombay Presidency', in Gazetteer of the Bombay Presidency, Vol. XXV: Botany, J. C. Lisboa, W. Gray and G. H. D. Wilson, Government Central Press, Bombay, I886, Part I, pp. i-xiv, $\mathrm{I}-307$.

${ }^{23}$ Letters sent by José Camillo Lisboa to Herbert Giraud and William Thiselton-Dyer at Kew Gardens, I88os and I89os, Library and Archives at Royal Botanic Gardens, Kew, Directors Correspondence I54.

${ }^{24}$ Although the imprint of the book gives I896 as the publication date, it appeared on the market only after Lisboa's death in I897. See obituary in the Fournal of the Bombay Natural History Society, vol. I I, no. 2, I897, p. 339. The list was first published as 'Bombay Grasses' in six parts in the Fournal of the Bombay Natural History Society, vol. 5, no. 2, I89o, pp. I I6-I3I; vol. 5, no. 3, I89o, pp. 226-232; vol. 5, no. 4, I89o, pp. 337-349; vol. 6, no. 2, I891, pp. I89-219; vol. 7, no. 3, I892, pp. 357-390; and vol. 8, no. I, I893, pp. I07-II9.

${ }^{25}$ Abreu, Noção de alguns filhos distinctos, p. 28.

${ }^{26}$ S. L. Gonsalves, 'Community and Identity. A Case Study of Luso Indian Participation in the Medical Profession in Nineteenth Century Bombay', MPhil thesis, SOAS University of London, 2008, pp. I09-1 I0. 
Lisboa appears to have been well regarded in the medical and botanical communities, as is suggested in an obituary which also acknowledges his wife's work:

Dr. Lisboa had a long and successful career in Medicine, (...). He made grasses a special subject of study and with the assistance and sympathy of his amiable and accomplished wife, acquired a truly remarkable knowledge of the structure and affinities of that very difficult group of plants. In private live he was all that good men wish to be, and his loss is widely deplored. ${ }^{27}$

Obituaries for Lisboa appeared in several high-ranking journals, which underline his respected position in academic circles. His wife endowed the J. C. Lisboa gold medal for high-performing students at Grant Medical College, which kept his memory alive there. ${ }^{28}$

In a few instances, Lisboa's outlook on life and clues to his personal experiences can be gleaned from the odd remark in his academic and political writings. One of these rare insights into how Lisboa perceived his work - a remark which illustrates his patience and persistence, and the involvement and energy he put into his botanical activities - can be found at the end of the sixth part of his Bombay Grasses papers, published in the Fournal of the Bombay Natural History Society in I893. In this, Lisboa slips in a personal note which reflects his attitude to his research:

Persons who have never considered the subject are not aware of the difficulties one has to encounter in an undertaking of this kind. I had to work as stated elsewhere, under great disadvantages; but I went on with patience and cheerfulness, because the work I had undertaken was a labour of love. ${ }^{29}$

'Auteur d'une connaissance exceptionnelle': ${ }^{30}$ Paramananda Mariadassou

Further south on the east coast and a couple of decades later, Paramananda Mariadassou, a younger colleague of José Lisboa, practised medicine as the first Tamil doctor in the French Indian

${ }^{27}$ Anon., 'Obituary: Dr. J. G. Lisboa', Fournal of the Bombay Natural History Society, vol. II, no. 2, 1897, p. 339 .

28 The medal was presented once a year; see, for instance, The Bombay University Calendar I93I, University of Bombay, I93I, p. 664.

${ }^{29}$ J. C. Lisboa, 'Bombay Grasses. Part VI', Fournal of the Bombay Natural History Society, vol. 8, no. I, I893, pp. I07-II9, quote on p. II9.

30 'An author of exceptional knowledge'. 
enclave of Pondicherry. Mariadassou, born in $1874,{ }^{31}$ belonged to a long-established Tamil family that had come to Pondicherry after his ancestor Paramanandappa converted to Catholicism. Though his father would have preferred him to become a lawyer, Mariadassou changed track and studied medicine. He opened the first private clinic, Sainte Anne, in Pondicherry. In addition to his professional career as a doctor, he wrote articles and edited two journals. Both weeklies appeared in French and Tamil, discussing topics on pertinent political issues, often with a critical edge. The French colonial government censored numerous articles and banned the publication of one of the journals during the First World War. However, Mariadassou persisted, renamed it, and ensured its weekly appearance. ${ }^{32}$ A decade-and-a-half later, in the 1930s, he discontinued his journalistic activities and, again, turned to academic writing and publishing on Indian medical systems, a subject he had already investigated during his time in Bordeaux and Rochefort.

Mariadassou received several medals and awards during his lifetime, of which only a few will be mentioned here. He was made a Chevalier of the Legion d'honneur au titre indigène in $1938{ }^{33}$ For his work on local medical systems, he received the Prix Catherine Hadot (hygiène) posthumously, together with two colleagues, in $1956 .^{34}$ Furthermore, Mariadassou was a member, and for the last 16 years of his life until his death in 1948, the president of the Association de médecine de l'Inde française. Moreover, he was instrumental in keeping the journal of the association, Le Foyer Médical, going. Some colleagues paraphrased

${ }^{31}$ Archives nationales d outre-mer (ANOM), Gouvernement Générale d'Indochine (GGI) 32640; in contrast, the year 1870 is given as Mariadassou's date of birth in V. Nallam, Histoire de la médecine de l'Inde française 1763-1962, Mission Press, Pondicherry, 2015, p. II7.

${ }^{32}$ Sri Soundjarnarandjini was first published in 1893 and is listed in V. Tantet (comp.), Catalogue méthodique de la bibliothèque du ministère des Colonies, Imprimerie Administrative, Melun, I905, p. 626, as an 'unofficial colonial publication'. For the banning of the journal in 1918, see Fournal officiel des établissements français dans l'Inde, vol. 69, no. 25, 22 juin I918, p. 273. Despite the ban and the journal's temporary name, Djanarandjini, it continued to flourish and is still listed in the Argus's mid-rg2os list of French-language publications across the globe: L'Argus (Paris), Nomenclature des journaux, revues, périodiques français paraissant en France et en langue française à l'étranger, Argus, Paris, I926-I927, p. 504.

${ }_{33}$ Fournal de Débats Politiques et Litteraires, vol. I5o, no. 58, io mars 1938, p. 6; Le Figaro, vol. II3, no. 69, io mars I938, p. 2.

${ }^{34}$ Anon., 'Séance de i decembre 1956', Bulletin de l'Académie nationale de médecine, vol. I40, no. $34-35$, г956, p. 6r9. 
Mariadassou's work in their papers, others praised it in reviews. For instance, his publication on astrology was said to demonstrate his exceptionally wide knowledge of Indian (medical) scriptures and practices: 'Le Dr Paramananda a remarquablement réussi dans cette tâche: ses travaux donnent une idée de la richesse des connaissances que, bien longtemps avant Rome et Athènes, l'Inde avait su acquérir [...] ${ }^{35}$

Mariadassou engaged with so-called Eastern and Western medicine in his academic writing. In most of his works, he mentions family members as well as friends. He recognizes their support through his years of study and of being abroad, for instance, in the series of dedications in his published doctoral thesis, in which he remembers his late father, then describes his mother as 'meilleure des mères', ${ }^{36}$ thanks his brothers with heartfelt gratitude, and finally refers to his uncles and cousins. Among his French advisers, Mariadassou includes his 'camarades' of the école de médecine in Pondicherry and 'all my friends in Bordeaux'. ${ }^{37}$ The sequence of the aforementioned individuals and the epithets chosen for them arguably reflects how significant his family members' endorsement seems to have been for Mariadassou in his professional endeavours. Perhaps his affection for family members is also underlined by the books he wrote for his children in later years. ${ }^{38}$

\section{'Lady doctor to take charge': Mary Poonen Lukose}

Moving from the southeast coast to the southwest coast of India, we encounter the youngest of the three individuals I introduce here: Mary Poonen Lukose. In I886, she was born Mary Poonen in Edathua, southwest of Changanasseri in erstwhile Travancore. ${ }^{39}$ Growing up as

35 'Dr Paramananda has been remarkably successful in this task: his oeuvre gives a glimpse into the rich knowledge which India had acquired long before Rome and Athens [...]'. Bienvenu, 'La vie scientifique', La médicine internationale: Revue mensuelle illustrée, vol. 3, mars 1907, pp. 472-477; Lasnet, 'Présentation d'un ouvrage imprimé', Bulletin de l'académie de médecine, vol. I23, no. 37-4I, I octobre I940, pp. 638-639, p. 638.

36 'The best of all mothers'.

${ }^{37} \mathrm{P}$. Mariadassou, Contribution a l'etude de l'extirpation du cancer du rectum par la voie abdomino-perineale, Y. Cadoret, Bordeaux, I899, n.p.

38 The titles of his children's books are, according to his son's lecture at the Societé d'Inde française des Sciences Médicales, 1950, the following: A bâtons rompus and Le jardin des roses non cueillies. H. P. Mariadassou quoted in Nallam, Histoire de la médecine de l'Inde française, pp. II7-I22.

${ }^{39}$ Poonen Lukose, 'My 86 Years', p. 20. 
an only child, Mary Poonen went to an English-speaking convent school in Thiruvananthapuram before studying science and medicine. Her professional career and political activities included many 'firsts': she was the first woman from the princely state of Travancore to graduate from Madras University with a BA in history, the first Indian woman to graduate in medicine from the University of London, the first female doctor in Travancore, the first female surgeon-general on the Indian subcontinent, and the first female member of the Travancore Legislative Council. Not only did she advocate adequate health facilities, particularly for women, in Travancore, but also women's political rights.

Besides her demanding schedule as a doctor and administrator, Mary Poonen Lukose co-founded the Thiruvananthapuram branch of the Young Women's Christian Association (YWCA) and served as its president for 50 years. She was also a member of two professional bodies, the Indian Medical Association and the Federation of Obstetric and Gynaecological Societies of India. ${ }^{40}$ Poonen Lukose received numerous honours, for instance, the Vaidyaśāstrakuśala awarded by His Highness the Maharaja of Travancore in 1935, and the Padma Śri awarded by the Government of India in $1975 .{ }^{41}$ Poonen Lukose's contributions to the health sector in Kerala featured in a recent budget speech by the finance minister of Kerala, in which he presented plans for the health sector for 2018. He emphasized that 'Dr Mary Poonen Lukose is one of the most talented people in the development of Kerala's health system. ${ }^{42}$

In her autobiographical essay, Mary Poonen Lukose reflects on her decision to become a doctor. She traces it to her early experiences helping out in hospitals where her father worked as a doctor, and to his

${ }^{40}$ K. Rajasekharan Nair, 'A Pioneer in Medicine: Dr. Mary Poonan Lukose (I8861976)', Samyukta, vol. 2, no. 2, 2005, n.p.

${ }^{41}$ T. K. Velu Pillai, The Travancore State Manual, vol. 4, I940 (reprint Government of Kerala, Thiruvananthapuram, I996), p. 582, www.dashboard-padmaawards.gov.in, [last accessed 8 October 2020].

42 'Kēralatile ārōgya samvidhāna valarččayil nirṇṇāyaka svādhīnam čeluttiya pratibhakalil orālāṇ dō Mēri Punen Lūkōs', T. M. Tōmas Isak, 'Badjat prasangam 20182019', Government of Kerala, 2 February 2018, http://www.finance.kerala.gov.in/bdgtSpch. jsp, [accessed 29 September 2020], and Anon., 'Kerala State Budget 2018: Remembering an Extraordinary Talent of Mary Poonen Lukose', The New Indian Express, 2 February 2018, http://www.newindianexpress.com/cities/thiruvananthapuram/2018/feb/o2/kerala-budget20I8-remembering-an-extraordinary-talent-of-mary-poonen-lukose-I767399.html, [accessed 29 September 2020]. 
example and influence on her: 'As I grew up, he made it a point to instil into me the spirit of service to humanity. ${ }^{43}$ Her notes evince her cognizance of being privileged and her determination to realize her ambition to take up a career as a medical doctor, a route that was rare for a woman at the time. The style of her igi6 job application, her requests for references, and the correspondence surrounding it suggest that she was aware of the fact that her qualifications were exceptional for an Indian woman of her time. She points out that she was the first woman from Travancore to graduate with a BA degree from the University of Madras, and the first woman to be a fully qualified medical doctor with a degree from the University of London. Her resolve to become a doctor from a young age shines through her writing - even though she often met with resistance from the (male) establishment. ${ }^{44}$ Poonen's professors in London spoke highly of her in references: 'She was an excellent student in every way, very much liked by her fellows, and popular with them and the Staff of the Royal Free. ${ }^{45}$

Lisboa, Mariadassou, and Poonen Lukose could pursue their careers because they were members of comparatively elite families. They had access to education and further studies, and their families - or wider networks of friends and well-wishers - possessed the means to support them. Again, all three were able to travel between different parts of the empires, including the metropole, without too much paperwork. The difficulties for them seem to have lain elsewhere, as at the same time, a distinct glass ceiling existed-linked to gender, race, and place of origin - which affected them. They had to go abroad, to the metropole, to achieve the qualifications required to practise as fully fledged doctors rather than as medical assistants only, which was the prescribed route for Indian medical personnel in the Portuguese, French, and British empires at the time. The physical mobility required in order to complete their training was a precondition for their partial social mobility.

${ }^{43}$ Poonen Lukose, 'My 86 Years', p. 22. The autobiographical essay covers Poonen Lukose's recollection of her childhood, student days, and ends with her taking up her position in Thiruvananthapuram in 1916.

${ }^{44}$ Various letters and application statement by M. C. Poonen, Asia, Pacific and Africa Collections, British Library (hereafter APAC): India Office Records (hereafter IOR) /L/E/ 7/859.

${ }^{45}$ Secretary and Warden, London Royal Free Hospital to Dr Mary Scharlieb, 8 February I9I6, APAC: IOR/L/E/7/859. 


\section{Striving for a degree: opportunities and challenges}

Across the Indian subcontinent, local systems of medicine such as Ayurveda, siddha, unani, and others, were taught through a combination of the formal reading of medical texts, observing, and later practising alongside an experienced doctor on his rounds in villages and towns. With European empires establishing their governments more formally, and with an increasing number of Europeans living in India who did not always see local medical practices as 'trustworthy' or 'professional', the demand for on-the-spot training in so-called Western medicine grew quickly. Thus, the need to facilitate 'treating the empire', that is, to provide medical care, emerged. Each European government handled this demand differently, but all of them began to introduce medical training institutions of some kind. Mostly, these were established to train medical assistants, nurses, or midwives, and quite openly did not provide options to gain further qualifications or the opportunity to complete a doctorate in medicine, which instead had to be gained at universities and hospitals in Europe. Circulation between metropoles and colonies was required in order to ensure that there were enough qualified Indian doctors who had been trained at European medical schools and were permitted to work in the colonies. In order to understand the circumstances in which our three protagonists had to negotiate their study options, their professional careers and personal lives, the wider context of chances for medical education in the metropoles, as well as the development of medical training facilities in Portuguese, French, princely, and British India, have to be considered.

\section{Traversing imperial boundaries: Fosé Camillo Lisboa}

After completing his studies in Latin and philosophy in Goa, José Camillo Lisboa went to Bombay and learned English. In I845, he enrolled at Grant Medical College in Bombay, along with three fellow students from Goa in the same cohort. ${ }^{46}$ In his second year, he was awarded the Anderson Scholarship 'for the $3^{\text {rd }}$ degree of proficiency' which came with a sum of Rs 15 in prize money. Thereafter he was promoted to the third year

\footnotetext{
${ }^{46}$ C. Morehead, Second Report of the Grant Medical College for the Mear ${ }_{1846-1847}^{8}$, Education Society's Press, Bombay, I849, p. 53.
} 
of study. ${ }^{47}$ Shortly after completing his medical diploma in I85I, Lisboa became assistant surgeon at the Jamsetjee Jejeebhoy Hospital, moving on to an appointment as a surgeon within a few months of joining. The training at Grant Medical College was firmly based on so-called Western medicine, and was taught by British teachers following a British curriculum.

Relations between British teachers and Indian students were, Sunil Pandya suggests, mostly amicable. ${ }^{48}$ However, when going back to reports written by the examiners in $185^{\mathrm{I}}$ (which were printed in the appendices of the Annual Report of the Grant Medical College), they appear to be saturated with paternalistic, racist undertones:

I trust I shall now be excused for making one or two remarks in justice in some measure to the Graduates, but due in a far greater degree to their talented, energetic and judicious teachers. [...] I had entertained doubts as to their [the graduates] reasoning powers [...]. Such knowledge could not have been acquired excepting by great industry on their parts but its acquisition has, in my opinion, been due in a far greater measure to the pains taken and to the judgement shown in their instruction by the Principal and the Professors. ${ }^{49}$

This quotation shows that examiner John McLennon made a distinct difference between the (Indian) students and the (British) teachers, thereby denying students the credit for their achievements and instead attributing it to their teachers. Furthermore, McLennon clearly doubts the ability of the Indian students to grasp the complexities of medical studies.

J. C. Lisboa decided to cross the imperial boundaries between Portuguese and British India, even though the Portuguese arena offered training in Western medicine too. Medical instruction in Portugal started in the fifteenth century, with the first students receiving some form of training at the Hospital de Todos-os-Santos in Lisbon, which was later transformed into the hospital of São José. Linked to the hospital, the Real Escola de Cirúrgia came into being in i825. An institution offering more formalized medical training emerged from it: the Escola Médico-Cirúrgica de Lisboa, which was established in 1836.

${ }^{47}$ C. Morehead, Third Report of the Grant Medical College for the Mear 1847-1848, Education Society's Press, Bombay, I849, pp. 37, 4I.

${ }^{48}$ S. Pandya, Medical Education in Western India: Grant Medical College and Sir Famsetjee Fejeebhoy's Hospital, Cambridge Scholars Publishing, Newcastle upon Tyne, 20I9.

${ }^{49}$ Quoted from the Annual Report of the Grant Medical College: Fifth Year-Session I850-5I, Education Society's Press, Bombay, I851, as printed in Pandya, Medical Education, p. 222. 
Some 80 years later, with the founding of the University of Lisbon in the wake of the establishment of the first Republic, the medical school was integrated into the Faculty of Medicine. ${ }^{50}$ Similarly, the University of Porto was established in I9II, based on predecessors that include the Medical-Surgical Academy of Medicine, which had been in existence since $1827 .^{51}$

Portuguese India saw the formal establishment of the Escola Médico-Cirúrgica de Goa in 1842 . It has been claimed that this was the first medical school that taught allopathy in India in a systematic way. ${ }^{52}$ Here, medicine was taught in conjunction with the military hospital. It began as a small school, with four teachers teaching a four-year medical course, and gradually expanded to include midwifery courses. José Lisboa might have decided against being trained in Goa because the school appears to have struggled to obtain sufficient and up-to-date learning materials and appropriate support from the local and metropolitan governments; despite this, it still managed to train more doctors than could find positions in Goa. Many went to other parts of the Portuguese empire, including Portuguese Africa, or crossed empire boundaries to Bombay. ${ }^{53}$ The medical school was also responsible for the health service in Goa. As the only such institution outside Lisbonbut within the Portuguese empire-Goa's medical school occupied a key position in training doctors for all regions of the empire - although, according to Cristiana Bastos, not even the authorities in Portugal recognized the degrees taken there. ${ }^{54}$ Nevertheless, Goan doctors practised across the empire and took up further studies in Lisbon or other imperial metropoles if they so wished and if they had the means to do so. One of them was José Lisboa, who had decided to move to

${ }^{50}$ L. da Silveira Botelho, 'A Escola Médica do Campo Santana', Acta Médica Portuguesa, vol. 8, I995, pp. 259-264. The roots of the University of Lisbon go back to the first university school, the Escola Geral, of I29o.

${ }^{51}$ R. M. Pinto Costa and I. C. Vieira, 'O lugar da medicina tropical nas dissertações da escola médica portuguense, I875-1923’, História, Ciências, Saúde-Manguinhos, vol. 21, no. 2, 2014, pp. 629-639.

${ }^{52}$ da Silva Gracias, Health and Hygiene, p. I75. Cristiana Bastos contends that the perception of the Goa Medical School as the oldest in Asia refers to its predecessor institutions of the sixteenth and eighteenth centuries. C. Bastos, 'Doctors for the Empire: The Medical School of Goa and its Narratives', Identities, vol. 8, no. 4, 200I, pp. $517-548$, p. 525 .

53 da Silva Gracias, Health and Hygiene, pp. 178-185.

${ }^{54}$ C. Bastos, 'The Inverted Mirror: Dreams of Imperial Glory and Tales of Subalternity from the Medical School of Goa', Etnográfica, vol. 6, no. I, 2002, pp. 59-76, p. 6r. 
British India, learn English in Bombay, and then study medicine within the British curriculum. British India was much larger than Goa and, thus, potentially offered more scope for a professional career.

\section{Moving to metropolitan France: Paramananda Mariadassou}

Educated at the Petit Seminaire de Pondichéry, Paramananda Mariadassou learned Latin, English, and Ancient Greek in addition to having been schooled in a Tamil primary school. After completing the baccalaureate in humanities at the Collège Colonial, Mariadassou studied medicine at the École de médecine in Pondicherry 'où il a fait trois années de brillantes études'. ${ }^{55}$ In order to undertake further studies and to obtain a doctoral degree, Mariadassou moved to Bordeaux. There, he finished his doctoral thesis in the academic year $1898-99 .{ }^{56}$

Mariadassou's educational trajectory reflects the strong military connection in French medical training, particularly with respect to the colonies. Medical education in France took place in the navy and army as well as in institutions for civilian medicine, which constituted three distinct spheres in teaching medicine. The army mostly generated their own medical personnel through practical training and basic instruction in anatomy. During the eighteenth century, more emphasis was given to founding civilian medical schools; these were established in Paris, Montpellier, Bordeaux, and Strasbourg, where the emphasis was on theoretical rather than practical teaching. The Bordeaux school trained both naval and colonial doctors. At the same time, naval medical schools were founded in Brest, Rochefort, and Toulon, all of which had hospitals attached. Two further naval hospitals were built in Cherbourg and Lorient, which attracted students from the region. ${ }^{57}$ In the nineteenth century, medical education in France was increasingly professionalized and standardized. The trend continued in the twentieth century: regional centres lost their importance as medical education became steadily centralized, with the main hub located in Paris,

\footnotetext{
55 'Where he excelled in his studies for three years'. Anon., 'Une bonne nouvelle', $L e$ messager de l'Inde, vol. 2, no. 5, I6 janvier igoi, p. 27.

${ }^{56}$ Anon., 'Thèses de la Faculté de Bordeaux', Gazette Hebdomadaire de médecine et de chirurgie, vol. 4, no. 85, 22 octobre i899, pp. Iо16-IоI7.

${ }^{57}$ M. Osborne, The Emergence of Tropical Medicine in France, University of Chicago Press, Chicago and London, 2014, p. I3.
} 
represented most prominently by the Pasteur Institute and the Paris Faculty of Medicine.

Across the French empire, various medical schools emerged. The first was established as the École de médecine de Pondichéry in i863. It was here that Mariadassou read medicine before going on to further studies in France. The establishment of the medical school in Pondicherry was followed by others in Alger (1879), Tananarive (I896), Hanoi (1902), and Dakar (1918). ${ }^{58}$ In January I890, the corps de santé des colonies et des pays de protectorat was created by presidential order. It was in charge of the health of individuals in the colonies, Europeans and local population alike, but could not provide blanket coverage of all parts of the empire. Here, the medical schools in the colonies were supposed to support the corps - albeit on a clearly defined level of 'assistance' rather than on an equal footing - as highlighted by the example of Paramananda Mariadassou. The medical school of Pondichéry flourished and continued its training for locals throughout the colonial period. $^{59}$ However, medical degrees awarded in the colonies were regarded as second rate everywhere in the French empire. In Paramananda Mariadassou's case, the judgement of official employers that locally awarded academic achievements were substandard can be seen in the issues he faced throughout his professional career (see below).

\section{Between princely state and imperial metropole: Mary Poonen Lukose}

Mary Poonen Lukose was denied admission to do a science degree on the basis of being a woman. However, she remained firm in her resolve to study medicine: 'But, right from school days all along the urge to take up medicine as a profession was taking shape in me, and my father was inclined to give his support to my pet idea. ${ }^{60}$ Through her own determination, and with her father's encouragement, she managed, against all odds, to overcome residues of resistance and to enrol for a BA in history at His Highness the Maharaja's College (affiliated to the

${ }^{58}$ D. Richard-Lenoble, M. Danis and P. Saliou, 'La médecine tropicale d'hier à aujourd'hui', Bulletin de l'Académie Nationale Médecine, vol. I97, no. 7, 2013, pp. 1353-1364, p. 1360 .

${ }^{59}$ After the integration of French Pondichéry into the Indian Union in I954/ı962, it was re-established as the Jawaharlal Institute of Postgraduate Medical Education and Research (JIPMER). Ever since, it has offered the full range of medical training.

${ }^{60}$ Poonen Lukose, 'My 86 Years', p. 2 I. 
University of Madras). Both Mary Poonen's first arts exam and her BA degree were perceived to be remarkable, so much so that they resulted in a gold medal being presented to her. This also prompted newspaper articles illustrating the achievements of women who took up tertiary education - not the most commonplace undertaking anywhere in the world at the beginning of the twentieth century. ${ }^{61}$

In order to realize her ambition to study medicine and become a doctor, Mary Poonen had no other choice but to embark on a journey to Europe. Universities in British India did not provide the opportunities for fully fledged further studies, as they were established with the aim of producing - male - government employees. ${ }^{62}$ Thus, Poonen spent several years at the University of London, where her 'position was unique even among the freshers, as I was the only one from India'. ${ }^{63}$ Besides studying the standard curriculum, Poonen sought opportunities to gain practical experience in various medical fields by observing and working with physicians in their evening and night-time clinics. In her vacations, she actively sought out other hospitals to gain further skills in specific areas. For instance, she practised at London's Great Ormond Street Hospital for Children and went to Rotunda Hospital in Dublin - the first time in the summer of 1914-where she had the opportunity to deepen her knowledge and training in midwifery. Mary Poonen was awarded her MBBS from the University of London in 1915 and received a prize of five guineas. She opted to do further studies and returned to Dublin to take the Diploma of Licentiate in Midwifery which she completed in December $1915 .{ }^{64}$

In the British sphere, the education of medical personnel took place at universities and royal colleges in the metropole, mostly in London, Oxford, Cambridge, and Edinburgh. Nascent formalization of medical training can be traced back to the London College of Physicians, which was established in 1518 . Two centuries earlier, instruction in medical

${ }^{61}$ Madras Mail, 8 February igo6, 6 March igo9, and 29 July igo9.

${ }^{62}$ T. B. Macaulay, 'Minute', 2 February I835, http://www.columbia.edu/itc/mealac/ pritchett/oogenerallinks/macaulay/txt_minute_education_I835.html, [accessed 3o September 2020]; V. Nagam Aiya, The Travancore State Manual, vol. 2, I9o6 (reprint Asian Educational Services, Madras, I989), p. 449, observes that many graduates of the higher education institutions occupied posts in government services, both in Travancore and in British India.

${ }^{63}$ Poonen Lukose, 'My 86 Years', p. 27. The maharaja of Travancore supported her financially: Dr Mary Scharlieb to Lady Dufferin, io February I9ı6, APAC: IOR/L/E/ 7/859.

${ }^{64}$ Poonen Lukose, 'My 86 Years', pp. 37-43. 
subjects had started at the University of Oxford, with Cambridge following in the I540s. Through the centuries, relations between the royal colleges and the universities ranged from strained to cooperative. Processes of standardization and professionalization were continuously put in place, particularly from the nineteenth century onwards. ${ }^{65}$ Students from India needed appropriate qualifications and sufficient funds to study at one of these metropolitan institutions. Poonen Lukose had the privilege of receiving the necessary moral and financial support from her family. The most crucial ingredient, however, was her deep conviction and her resolve to become a doctor, which enabled her to overcome impediments and obstacles, often connected to her gender, throughout her career.

From the nineteenth century onwards, the British colonial government established a series of medical colleges and universities offering allopathic courses in India. A first attempt was made in Calcutta with the Native Medical Institution (NMI), where, supposedly, a combination of local medical systems and so-called Western medicine was taught. However, the NMI survived for only a few years ${ }^{66}$ and was replaced by the Medical College of Calcutta in i835. Madras Medical College was established in the same year, whereas Grant Medical College in Bombay only opened its doors in I845. According to David Arnold, this demonstrated that '[e]ven more than previously, Western medicine after I835 was taken as the hallmark of a superior civilisation, a sign of the progressive intentions and moral legitimacy of colonial rule in India $[\ldots],{ }^{67}$ In the princely states, which came under indirect British rule, British residents observed the governance and political strategies of royal families, although they were nominally 'independent' with respect to internal affairs, including education. The maharanis and maharajas of Travancore initiated and promoted education in Travancore. Between the I860s and I880s, they established a series of eight colleges, among them His Highness the Maharaja's College at which Poonen Lukose studied for her BA. However, all colleges in Travancore came

${ }^{65}$ On the standardization and professionalization of medical training in Britain, see V. Nutton and R. Porter (eds), The History of Medical Education in Britain, Rodopi, Amsterdam, I995, pp. I-I5; for a comparative view, see T. N. Bonner, Becoming a Physician: Medical Education in Britain, France, Germany, and the United States, I750-1945, Oxford University Press, New York, I995, particularly pp. 280-308.

${ }^{66}$ See D. Arnold, Science, Technology and Medicine in Colonial India, Cambridge University Press, Cambridge, 2000, pp. 62-63.

${ }^{67}$ Ibid., p. 63 . 
under the control of Madras University. ${ }^{68}$ The first medical college in Travancore was inaugurated only after the independence of India, in the early I950s. Other princely states had started this initiative a century or several decades earlier. The nizam of Hyderabad established the Hyderabad Medical School in I846 (later named Osmania Medical College). Mysore Medical School was founded in I917, and upgraded to Mysore Medical College in 1924. The great variety between princely states in terms of size, population, and style of governance was reflected in their policies with respect to health services and education. ${ }^{69}$

In line with the Indian Civil Service (ICS), the Indian Medical Service of British India was created in 1857/8. It brought the Bombay, Bengal, and Madras Medical Services, which had been established in the eighteenth century, under one administrative roof. Originally, they were by and large meant to attend to the British locally, and to assist in cases of epidemics in the local population. They had emerged from the military medical services that had accompanied the ships of the East India Company on their voyages. Until the I850s, individuals who wished to work in the Medical Service did not require specific medical training. In 1905, Indians constituted circa 5 per cent of the members of the IMS; in I938, this was circa 37 per cent. The IMS was abolished at independence; from 1947, local governments were responsible for the provision of healthcare. ${ }^{70}$

On the surface, medical students and practitioners who circulated between local and metropolitan institutions provided the foundation for medical provision. However, what appears to have been an easy 'flow' between different parts of empires becomes more complicated when looking behind the scenes: movements were regulated and restricted by various means. Perhaps the most important aspect of channelling physical mobility was through legislating citizenship rights. Channelling social mobility mostly functioned through hierarchically structured medical services based along racial, gender, class, and caste lines. While movement between parts of one empire or between metropoles and colonies of different empires was comparatively easy during the nineteenth century, regulations became more restrictive in the first

${ }^{68}$ M. Frenz and G. Berkemer, 'Colleges and Kings: Higher Education under Direct and Indirect Rule', Economic and Political Weekly, vol. 4I, no. I3, 2006, pp. I26I-I268.

${ }^{69}$ See W. Ernst, B. Pati and T.V. Sekher, Health and Medicine in the Indian Princely States I850-I950, Routledge, London, 2018.

${ }^{70}$ M. Harrison, Public Health in British India: Anglo-Indian Preventive Medicine 1859-19I4, Cambridge University Press, Cambridge, 1994. 
decades of the twentieth century, particularly during and after the First World War. In the war years, closer control of who moved where, when, and for what reason was implemented through tighter citizenship and passport rules. This affected freedom of movement, especially for individuals living in the colonies. Constraints regarding professional careers remained in place in all European empires throughout the colonial period.

\section{Practising for the people: professional and public service}

Opportunities for individuals to advance their profession, like obtaining a degree, involved another set of chances and challenges. The movement of those of Indian origin was regulated by all three imperial powers, as were possibilities to practise professions. Citizenship regulations, as well as hierarchical structures governing imperial services for medical, legal, and clerical work, often prevented Indians from rising through the ranks. Reasons were more often than not compounded by issues relating to questions of gender, race, class, and caste. Lisboa, Mariadassou, and Poonen Lukose actively pushed boundaries to increase their room for manoeuvre. Although they encountered numerous incidents which kept them from achieving their objectives, they committed themselves to the greater common good, be it by advancing science, engaging in learned societies, caring for the well-being of everyone in society, or participating in political pursuits. ${ }^{71}$ In the following section, some of these tensions will be investigated.

With the introduction of passports across empires, the question arose as to what this meant for individuals who wished to travel between countries or empires. ${ }^{72}$ Citizenship, in this context, was perceived to be linked to a

${ }^{71}$ M. Frenz, 'From Zebra to Motorbike: Transnational Trajectories of South Asian Doctors in East Africa, c. 1870-1970', in Doctors beyond Borders. The Transnational Migration of Physicians in the Twentieth Century, L. Monnais and D. Wright (eds), Toronto University Press, Toronto, 2016, pp. I42-165.

${ }^{72}$ Passports were abolished in most European countries in the early nineteenth centuryin Britain and its empire, for instance, in I826. The pendulum swung back again towards the end of the nineteenth century with occasional passports being issued. With the First World War and the restrictions on movement announced by various governments, passport regulations were created on a wider basis and increasingly became a requirement for travel. See J. Doulman and D. Lee, Every Assistance and Protection. A History of the Australian Passport, Federation Press, Leichhardt, NSW, 2008, p. I3. The only passport I could find 
nation or an empire, contrary to the concept and practice of citizenship in ancient Rome. There, citizenship was thought more inclusive; it was meant to be universal. ${ }^{73}$ This notion, however, changed profoundly in later centuries when citizenship came to represent belonging to a political entity with citizens enjoying rights and bearing obligations. In other words, 'citizenship is [...] the right to claim rights'. ${ }^{74}$ The notion and definition of citizens within a state being equal and enjoying 'full membership of a community ${ }^{, 75}$ evolved after the French Revolution of I789, when questions of citizenship were fiercely debated and newly defined. ${ }^{76}$ Despite the aspiration to make every individual equal before the law, however, certain classes within the metropoles and colonies were excluded from this ideal of equality. In the Portuguese, French, and British spheres, the "rhetoric of equivalence" 77 was maintained in theory, but in practice, legal traditions evolved which were often based on differentiating individuals on grounds of their cultural, religious, or other backgrounds.

\section{'Devoted to one and the same purpose': Fosé Camillo Lisboa}

Lisboa's career as a doctor was inextricably linked to his ability to cross the borders between the Portuguese and the British empires. Looking at the records available, he did this for the first time after completing his studies in Goa. He moved to Bombay to learn English, stayed on, and studied at Grant Medical College, as mentioned above. Lisboa remained in Bombay throughout his career. Over the years he worked at Jamsetjee Jejeebhoy Hospital as an assistant surgeon and he held an interim appointment as lecturer in anatomy at Grant Medical College in the I850s. A few years later, Lisboa set up his own private clinic in Bombay, because he-like his British-Indian colleagues - was excluded

for any of the individuals looked at here is one for Mary Poonen Lukose. It dates from $193^{8 .}$ APAC: IOR/L/PJ/in/7/I386.

${ }^{73}$ See F. Cooper, Citizenship, Inequality, and Difference: Historical Perspectives, Princeton University Press, Princeton and Oxford, 2018, p. 7.

${ }^{74}$ Ibid., p. I9, quote on p. Io, emphasis in original.

75 T. H. Marshall, Citizenship and Social Class and Other Essays, Cambridge University Press, Cambridge, i95o, p. 8.

${ }^{76}$ W. R. Brubakers, 'The French Revolution and the Invention of Citizenship', French Politics and Society, vol. 7, no. 3, 1989, pp. 30-49, p. 30.

${ }^{77}$ Cooper, Citizenship, Inequality, and Difference, p. I9. 
from entering the Indian Medical Service. He continued to be called upon to support his colleagues in the operating theatre where he was a valued member of the team. For around two years in the i86os, he travelled and worked in Portugal, France, and England, without any issues concerning his passport or citizenship, according to available sources.

Despite the opportunities Lisboa could have taken advantage of, for example, by leaving the Portuguese realm to work in one of the British directly ruled cities of the subcontinent, he was faced with restrictions on where and how he could practise his profession. The exclusive nature of the Indian Medical Service, which selected members on the basis of their race and origin, rather than on merit, illustrates the glass ceiling Indian doctors encountered throughout the nineteenth century and far into the twentieth. Possibly these experiences provided the incentive for Lisboa to engage with professional societies, such as the Grant Medical College Society and the Medical Union. He was not only a member, but was actively involved, elected as the president of the former for ten years, and of the latter for four years. ${ }^{78}$

During his tenure as the president of the Grant Medical College Society, Lisboa emphasized how important its activities were. In his view, its objectives lay in two main areas: as a hub for exchanging the latest insights in medical research, and as a professional body to bring together men of all social backgrounds. Lisboa himself used the Society's platform to present his own studies on leprosy, in which he analysed the stages different varieties of leprosy could take, discussed case studies of patients he treated, and referred to research undertaken by Norwegian colleagues. His observations were published in two parts in I874. These show that Lisboa was open to and treated patients with both allopathic and Indian medication:

[...] to bring to the notice of the society the effects of an Indian drug which I have tried for the cure of this disease with some apparent benefit. I have no doubt [...] it is worth our while to have attention drawn to the subject not only for the advancement of science but also for the relief of suffering humanity. ${ }^{79}$

${ }^{78}$ Anon., 'The Late Dr. J. C. Lisboa', ı897, p. I719.

${ }^{79}$ J. C. Lisboa, Papers on Leprosy: Read before the Grant Medical Society, Asiatic Printing Press, Bombay, I874, 2 parts; quote in Part 2, pp. 2, 21. One of his colleagues, Henry Vandyke Carter, apparently considered Lisboa to have been the first doctor in India to look into leprosy systematically. P. J. Peregrino da Costa, A Expansão do Goês pelo Mundo, Edição da Repartição Central de Estatistica e Informação, Goa, I956, p. I29. 
In terms of the Society's second set of objectives, its aims, according to Lisboa, were to maintain and promote a strong work ethos.

The President points out that a Medical Society should be not only an arena for discussion of subjects of medical interest: but should, also, encourage and stimulate original research, constitute a bond of professional union, and a tribunal of professional ethics. [...] The Society would also constitute a common meeting ground of medical men of all castes, colours and nationalities, and promote fellowship among men whose lives are devoted to one and the same purpose. ${ }^{80}$

Both quotes illustrate J. C. Lisboa's twofold approach to his research, his practice, and his honorary activities: driven by excellence in research, he did not lose sight of the underlying need to cure patients or, at least, to reduce their afflictions. In his presidential speech, Lisboa emphasizes the importance of professional conduct and perceives all doctors, irrespective of their sociocultural or religious backgrounds, as colleagues on a par with one another. His claim to equality is paired with a plea for social responsibility. From today's perspective, it is noteworthy that Lisboa does not include women in his statement. Although he came across discriminatory practices during his professional career, which were based on race and, possibly, on caste, he himself did not seem to question the male-only arrangements in the context of his job and his activities in professional associations. On the other hand, he seems to have worked as a team with his wife Julia who presented some of their/her research and published it. They created a universe of botanical knowledge, with their last name present in the denomination of two grasses. In his own way, Lisboa widened the scope of action available to him as a colonial citizen through his innumerable ventures: his (and his wife's) academic work, discussed with and among botanists the world over; his understanding of working side by side with medical professionals from any social background; and his journalistic pieces in political magazines.

J. C. Lisboa's comparatively trouble-free experiences of moving around parts of empires and between empires may have been based on the conceptualization of citizenship which prevailed in the Portuguese empire and thus in Goa. In early nineteenth-century Portugal, inhabitants of both the metropole and the colonies were imagined to be equal. They were accorded the same status as citizens-'todos os

${ }^{80}$ Anon., 'The Grant College Medical Society Bombay', Indian Medical Gazette, vol. I4, no. Iо, I879, pp. 286-287, p. 286. 
Portugueses são cidadãos ${ }^{81}$ - with no distinction being made between inhabitants of the metropolis and those of the colonies or provinces: 'a Nação Portuguesa é a união de todos os Portugueses de ambos os hemisférios'. ${ }^{82}$ The idea of everyone - wherever they lived - being equal was, however, not necessarily translated into practice either in Portugal itself or its wider empire. Rui Ramos argues 'that while it was easy for residents and their descendants to become Portuguese nationals, it was difficult for Portuguese nationals to become full citizens' and that 'citizenship was used as a means to legitimize political and social exclusion' ${ }^{83}$ One instance of exclusionary politics relates to suffrage: although the 1822 constitution states that every male citizen had the right to vote, article 33 restricts this right: illiterate individuals, monks, servants, and others were excluded. ${ }^{84}$ Successive liberal governments continued to add to this list, for instance, by excluding individuals below a certain economic level. ${ }^{85}$ In the 1870 , voting rights were extended for a short period to include all adult males who headed a household, but restrictions were imposed again just 15 years later. Remarkably, the exclusion of individuals from suffrage soared after the republic had been installed in I9IO, with over three-quarters of men denied voting rights. True to republican ideals, citizens were granted equality before the law, and laicism was introduced in the first republican constitution of Portugal. ${ }^{86}$

81 'All Portuguese are citizens.'

82 'The Portuguese nation is the union of all Portuguese [people] of both hemispheres.' Portuguese constitution of i822: Constituição Politica da Monarchia Portugueza, Declarada pelas Cortes Geraes Extraordinarias e Constituintes, reunidas em Lisboa no anno de oitocentos vinte e um, articles 20, 2I. The constitution was ratified on 23 September i822. See also J. Duffy, Portuguese Africa, Harvard University Press, Cambridge, MA, I96I, p. 75. Consecutive Portuguese governments changed the terminology of colónias and provincias in regular intervals; de facto, both terms were used interchangeably.

${ }^{83}$ R. Ramos, 'Portuguese, but not Citizens: Restricted Citizenship in Contemporary Portugal', in Lineages of European Citizenship: Rights, Belonging and Participation in Eleven Nation-states, R. Bellamy, D. Castiglione and E. Santo (eds), Palgrave Macmillan, Basingstoke, 2004, pp. 92-II2, pp. 92, 93.

${ }^{84}$ Constituição Politica da Monarchia Portugueza, Declarada pelas Cortes Geraes Extraordinarias e Constituintes, reunidas em Lisboa no anno de oitocentos vinte e um, article 23.

${ }^{85}$ Ramos, 'Portuguese, but not Citizens', p. 95. It seems that liberals who took part in the debates about the formulation of the constitution were in close contact with Jeremy Bentham and read his oeuvre. C. Fuller. "Primeiro e mais antigo Constitucional da Europa": Bentham's contact with Portuguese liberals I820-23', Fournal of Bentham Studies, vol. 3, 2000, pp. I-I3.

${ }^{86}$ Portuguese constitution of I9ı: Constituição Politica da República Portuguesa, ratified on 2I August I9I by the Constituent National Assembly, articles 2, 4 . 
Just over two decades later, the Estado Novo ratified yet another constitution. It cloaked its authoritarian aspirations in the language of citizenship. Women were granted electoral rights only in 1968.

In the colonies - or provinces - the notion of the equality of all citizens was frequently not manifested in practice: it was expected that the local populations in Africa and Asia would take on Portuguese customs and values through a process of assimilation. Once this was successfully completed, they would then become a cidadão (citizen) with political rights. Consequently, three distinct groups existed: Portuguese citizens, assimilados, and indigenas (local population). The status of assimilado had to be applied for. ${ }^{87}$ This became particularly explicit with the passing of the Acto Colonial in 1933, which emphasized the need to educate populations in the overseas territories. 'Colonial social control and coercion' ${ }^{88}$ were acutely felt across the empire.

Throughout the nineteenth and twentieth centuries, the relationship between the metropole and the colonies/provinces was characterized by an inherent tension. This in turn was fuelled by constant changes in the constitution, outlook, and style of government. The official rhetoric rendered a picture of equally free individuals who were deemed to be citizens, even if realpolitik more often than not made clear distinctions between cidadãos, assimilados, and indígenas. These continued even though in I95I, the notion of Portugal as a colonial state was abandoned by law and the country now portrayed itself as a 'greater nation'. ${ }^{89}$ Bernd Reiter argues that the differentiation between metropolitan and colonial Portuguese can be observed even in present-day Lisbon: according to him, the legacy of creating three main groups of individuals with different rights to citizenship is evident in the relationships between locally rooted Portuguese and Portuguese of African, Asian, or South American descent, and 'discursive practices that invoke Portugal's modernity, Europeanness, whiteness, and difference to the non-European world - and especially its distance to those people that were previously part of the pluricontinental

${ }^{87}$ Ana Horta and Paul White argue that many refrained from putting in an application for a change in status from indigena to assimilado to avoid the taxes that came with it. A. P. B. Horta and P. White, 'Post-colonial Migration and Citizenship Regimes: A Comparison of Portugal and the United Kingdom', Migrações, vol. 4, 2009, pp. 35-57, 39.

${ }^{88}$ M. B. Jerónimo and A. C. Pinto, 'A Modernizing Empire? Politics, Culture, and Economy in Portuguese Late Colonialism', in Jerónimo and Pinto, The Ends of European Colonial Empires, pp. 51-98, p. 51.

${ }^{89}$ Lei No. 2048 de in de Junho de I95I. 
Portuguese nation. ${ }^{90}$ Still, the myth of a global and encompassing Portuguese empire persists and still seems to be part of the self-image of Portuguese society today. Perhaps a handful of Indians could claim to lead the lives of globally acting citizens, even if that was not in terms of their formal, rights-based status. Rather, they-among them individuals like J. C. Lisboa - actively engaged in other levels of citizenship through their publicly visible professional, academic, and political ventures.

\section{'Respecter les us et coutumes': ${ }^{91}$ Paramananda Mariadassou}

Paramananda Mariadassou moved several times between metropolitan France and different parts of the French empire in South and Southeast Asia. His professional career depended on studying and gaining work experience in France: only French qualifications would allow him to practise at a similar level to European and French doctors - and only if the employer took his French qualifications into account. Mariadassou met with more than one obstacle when he searched for a job in Pondicherry after his return from Bordeaux. His French colleagues seem to have found it hard to work with a Tamil doctor whose qualifications equalled their own, as Mariadassou's son indicated in a lecture given at the Societé de l'Inde française des Sciences Médicales a couple of years after Mariadassou's death. ${ }^{92}$ The only avenue left open to him that allowed him to work in a position equal to his level of training was to become a doctor in the corps de santé des troupes coloniales. There, he was médecin aide-major de première classe. ${ }^{93}$ Apparently, however, this was not Mariadassou's first choice as he had to move between parts of French India: he was stationed in Chandernagar and Karaikkal. ${ }^{94}$ His sojourn included a stay in Rochefort, ${ }^{95}$ where he completed the training and exams necessary to become part of the

${ }^{90}$ B. Reiter, 'The Perils of Empire: Nationhood and Citizenship in Portugal', Citizenship Studies, vol. I2, no. 4, 2008, pp. 397-412, pp. 406-407.

91 'Respect the habits and customs'.

${ }^{92}$ H. P. Mariadassou, quoted in Nallam, Histoire de la médecine de l'Inde française, pp. II7-I22.

93 'Assistant physician of the first rank'. Anon., 'Nominations', Fournal officiel de la République française. Lois et décrets, vol. 35, no. 321, 26 novembre 1903, p. 7133.

94 Anon., 'Nominations officielles', Questions diplomatiques et coloniales: revue de politique extérieure, vol. 8, no. I8o, I6 août I904, pp. 267-270, p. 268.

${ }^{95}$ Le Matin, vol. 23, no. 8330, I8 decembre igo6, p. 4. 
corps des médecins des colonies. This also made him a qualified médecin maritime $^{96}$ and, at least in theory, opened up new opportunities.

An attempt to work in erstwhile French Indochina faltered, despite the degrees Mariadassou had completed at French higher education institutions in Bordeaux and Rochefort. His application to work at the hospital in Saigon in 1907 was rejected. Referring to the hierarchically and regionally structured French medical service, the rejection letter informs Mariadassou that '[...] les médecins indigènes ne peuvent être appelés à servir que dans les corps constitués par des militaires de leur race et dans les formations sanitaires de leur colonie d'origine. ${ }^{97}$ It clearly communicates that qualifications and professional experience were not the decisive factors in offering employment to an applicant; instead, their race and region of origin were more relevant. Both aspects are communicated in the original rejection letter, poignantly catching the reader's attention. It was on this basis that Mariadassou's metropolitan degrees were not even taken into account.

Back in South India, Mariadassou worked as a doctor in the French local medical service, again in $\mathrm{Karaikkal}^{98}$ — until he was asked to become part of a political game, which he declined to do. Consequently, a campaign was started against Mariadassou; he was accused of misconduct and sent off to serve in Chandernagar, around $5^{0}$ kilometres north of Kolkata. Even after his return from Chandernagar, political rancour continued. In a second attempt at securing a job in Indochina, more than 20 years after the first one, Mariadassou was offered a position at the military hospital Poulo-Condore in Indochina in 1928, where he worked for about two years. But he had to reapply for the same job every six months in order to have his contract renewed, even though his employer remarked that he had a good work ethic and did well. ${ }^{99}$ Upon his return to Pondicherry, Mariadassou decided to open up his own private clinic, which he named Sainte Anne. Many years later, in his sixties, he

96 'Maritime physician'.

97 'Indigenous physicians can only be recruited to serve in the military corps put together of members of their race and in health services of the colony of their origin.' 'Classement Médecine', ANOM, GGI 2786. Emphasis in original.

${ }^{98}$ A. Duprat, 'Arrête nommant M. le Dr Paramananda-Mariadassou, médecin du service local des établissements français dans l'Inde, et l'attachant à I'établissement de Karikal', Republique Française: Fournal officiel des établissements français dans l'Inde, vol. 52, no. 42, I7 octobre I9II, pp. IOOO-IOO2.

99 'Dossier de M[onsieur] Mariadassou', ANOM, GGI 32640. 
accepted an offer to take up a professorship for local Indian medicine at the École de médecine in Pondicherry. Many of his lectures were printed in the books he published in the following years. ${ }^{100}$

Throughout his career, Mariadassou studied aspects of allopathic and Indian medicine on which he published widely. In one of his frequently quoted monographs he remarks that he was a wanderer and intermediary between both worlds. His intention, he further contends, was to persuade Indians that allopathic medicine was applicable in India and to convince Europeans of the valuable properties of Indian medical systems:

Pour le moment, notre but serait atteint et notre ambition satisfaite, si nous pouvions faire comprendre: $I^{\circ}$ à tous nos concitoyens que la médecine européenne est parfaitement applicable dans l'Inde, que la latitude d'un pays ne peut être un obstacle à une science raisonnée telle que la médecine européenne; $2^{\circ}$ à nos collègues, qu'il y a de bons adjuvants dans les mours de l'Inde dont il faut savoir tirer parti, et qu'il faut avant tout ménager toutes les susceptibilités, qui, pour être bizarres, n'en sont pas moins ombrageuses. ${ }^{101}$

${ }^{100}$ Mariadassou's lectures were published in various editions, for instance, P. Mariadassou, Conférences faites à l'école de médecine de Pondichéry, 3 vols, Imprimerie Sainte Anne, Pondichéry, 1932-1934; P. Mariadassou, Conférences faites à l'école de médecine de Pondichéry, 4 vols, Imprimerie Sainte Anne, Pondichéry, I932-1935; P. Mariadassou, Matière médicale ayulvedique: Conférences faites à l'école de médecine de Pondichéry, 2 vols, Imprimerie Sainte Anne, Pondichéry, I936-I937 and I937-38. Mariadassou also published on various topics in the series Médecine traditionnelle de l'Inde, all published with the Imprimerie Sainte Anne, Pondichéry: Hygiène domestique, I948; Hygiène nationale, I947; Matière médicale inorganique, I945; Histoire de la médecine hindoue, 3 vols, deuxième édition revue, corrigée et augmentée, 1943-45; Us et coutume de l'Inde et hygiène alimentaire locale, vol. I, I940; Us et coutumes de l'Inde et matière médicale usuelle, vol. 2, I942; Astrologie hindoue, 2 vols, I940; Le rajeunissement par le Kayacarpam, 1938; Médecine usuelle, I938; Hygiène locale, 1938; La Magie noire, I937; Guide-formulaire de thérapeutique ayurvédique, 2 vols, vol. I, 1936; Pathologie general, vol. 2, s.a.; Pathologie spéciale, s.a.

101 'For the moment, our goal would be reached and our ambition satisfied, if we could make ourselves understood: First, for all our fellow citizens, that European medicine is perfectly applicable in India, that the geographical position of a country cannot be an obstacle for a science based on reason such as European medicine. Second, for our colleagues, that there are good supportive treatments among Indian practices, whose benefit should be known; and that, first of all, sensibilities need to be managed, that are, though odd, no less touchy.' P. Mariadassou, Møurs médicales de l'Inde et leurs rapports avec la Médecine européenne, Mission Press, Pondichéry, I9o6, p. 6. This monograph was published again a couple of years later in conjunction with a Parisian publisher: P. Mariadassou, Moeurs médicales de l'Inde dans leurs rapports avec la médecine européenne, A. Coccoz, Pondicherry and Paris, I9o8. 
In order to facilitate mutual understanding between European and Indian colleagues, Mariadassou also compiled a dictionary of Tamil names of medicinal plants. ${ }^{102}$ Mediating between Tamil and French concepts of treating patients entailed respect for other methods of curing the sick. Mariadassou's academic investigations and publications furthered both science and society. This demonstrates his social endeavour or a different way in which to engage in the pursuits of responsible citizens. Moreover, his political writings in the two Tamil-French journals he edited illuminate his agency in terms of publicly expressing his opinions.

For Mariadassou, it was a challenge to establish himself in his preferred career path. Although it was the French who initiated the concept of national citizenship based on the equality of all citizens, restrictions implemented in the nineteenth century led to a differentiated situation in the colonies. ${ }^{103}$ According to William Brubakers, 'the [French] revolution invented not only the nation-state but the modern institution and ideology of national citizenship'. ${ }^{104}$ The principle of equality before the law - at least as far as men were concerned - is one of the central achievements of the French Revolution: a society hitherto distinguished by privilege was henceforth characterized by the application of a common law. The citoyen was born. However, not everyone was deemed a citoyen: for instance, women were denied access to active and passive suffrage well into the Second World War (1944). The majority of the population was not allowed to vote and was called citoyens passifs. They included men below the age of 25 , servants, individuals whose wealth fell below a certain level, and anyone accused of a crime. In the French Constitution of I79I, citizenship was, for the first time, formally codified and applied in metropolitan as well as in colonial France. Simultaneously, the invention of the citizen and their rights within the nation-state led to the construction of the 'foreigner' or the 'other', who

\footnotetext{
${ }^{102}$ P. Mariadassou, Le jardin des simples de l'Inde, Mission Press, Pondichéry, I9I3.

${ }^{103}$ Paradigmatic for divisions in French Pondicherry is the nearly two kilometre-long canal which separated the so-called black and white city from I8I4. This was the geographic and political context in which Mariadassou and Pondicherians had to negotiate their professional and private lives. See P. Aubry and B.-A. Gaüzère, 'Histoire de la santé dans l'océan Indien: soins, prévention, enseignement et recherche du XVIIe siècle au milieu du xxe siècle', Médecine et Santé Tropicales, vol. 26, no. 2, 2016, pp. 122I29, p. I23.

${ }^{104}$ Brubakers, 'The French Revolution', pp. 30-49, p. $3^{\circ}$.
} 
was excluded from the community of citizens and the rights that came with it.

The Code Givil of I803, also known as the Napoleonic Code, prompted a seismic shift: civil and political rights were separated. Three aspects changed the way in which metropolitan and colonial populations would be seen in terms of their legal status: first, ius sanguinis (right of blood) replaced ius soli (birthright); secondly, civil status and the features associated with being a citizen became differentiated; and thirdly, women came to be seen as dependents of their husbands, affecting their right to citizenship or lack thereof. These regulations were reinforced in the nationality laws of 1889 and $1927 .{ }^{105}$ In practice, therefore, to be a French subject but not a French citizen meant that individuals were accorded a different juridical status: subjects in the colonies came under local jurisdiction rather than under the civil code, and did not have any voting rights in metropolitan France. Attempts at redressing this inequality in the I93os failed. Thus, multiple versions of citizenship existed. In I945, the four main categories were: first, metropolitan citizenship, held in European France; secondly, Muslim non-citizens and non-Muslim citizens in Algeria; thirdly, individuals in the old colonies such as French India, the Caribbean, and the Quatre Communes of Senegal, who had been accorded full citizenship rights in I848; and finally, individuals in the new colonies, which included most of French Africa and the Pacific islands, who were classified as French subjects. These four categories of individuals were considered to be French and part of the French Republic. Local populations of protectorates (parts of Indochina, Tunisia, and Morocco) and mandates (Togo, Cameroon) remained subjects of their local rulers. ${ }^{106}$ For the French government, 'overseas territories were $[\ldots]$ integral to a French "empire nation-state", where " $[\mathrm{t}]$ he lives of colonial citizens $[\ldots]$ were bound to be enhanced thanks to their complete immersion in French values'. ${ }^{107}$

${ }^{105}$ L. Semley, To Be Free and French: Citizenship in France's Atlantic Empire, Cambridge University Press, Cambridge, 2017, p. 207.

${ }^{106}$ F. Cooper, Citizenship between Empire and Nation: Remaking France and French Africa, 1945I96o, Princeton University Press, Princeton, 2014, p. 21.

${ }^{107}$ M. Thomas, Fight or Flight: Britain, France, and their Roads from Empire, Oxford University Press, Oxford, 2014, pp. 22-23. See also A. Conklin, A Mission to Civilize, Stanford University Press, Stanford, CA, I997, p. 22. 
Citizenship remained contested: in the - at times controversialnegotiations between France and its territories in the mid-I94os, attitudes held by representatives of metropolitan and colonial regions ranged from advocating imperial citizenship to implementing full French citizenship. ${ }^{108}$ In the process of decolonization, some French colonies became independent nation-states; others became a département of European France, such as La Réunion; and Pondicherry, with the other French Indian territories, became part of the Republic of India after a lengthy process of deliberations that was finalized in 1963 .

In sum, the revolutionary ideal of creating equal citoyens throughout the French empire stopped short with the reintroduction of differentiations between citizens and subjects under Napoleon and subsequent monarchies. This was further aided by a process of colonization of new territories in the early twentieth century that were put under different governance structures than earlier colonies, such as protectorates and mandates. The creation of an overarching imperial citizenship providing equal rights to every citoyen, such as was envisaged and implemented for a couple of decades after the French Revolution, did not materialize in the long term. The example of Mariadassou not being considered eligible because he was an Indian-born citoyen demonstrates the differentiated treatment accorded by French government institutions and employers towards potential employees: race and origin featured prominently in decision-making processes, long before qualifications and merit. Mariadassou's physical movement within the empire, facilitated by his French citizenship, does not seem to have been restricted. In contrast, his career mobility was circumscribed and hampered by his race and place of origin. This could not be 'healed' through qualifications and merit. Thus, Mariadassou's only options were to work in the military unit of Indians and in the assistant medical service (med auxiliaire) in French India where Indians were employed as assistants to European doctors rather than as doctors in their own right. Mariadassou's case illustrates the tension between a rights-based approach to citizenship in a restrictive colonial setting and creative ways of enacting substantive citizenship: Mariadassou made local medical treatments accessible to European colleagues, thus bridging local and European concepts of medicine, kept his integrity as a professional doctor, and wrote for and edited political journals, thus extending his scope for action.

${ }^{108}$ Cooper, Citizenship between Empire and Nation, passim. 
Mary Poonen took up her first job in January 1916 at a military hospital just outside London, where the war injured were being treated. Again, as in her first year of study, Poonen was the only Indian among the doctors. At the same time, knowing that her father was seriously ill, she applied for jobs in South India. ${ }^{109}$ When she received the news of her father's death in March I9I6, she contemplated staying in London. After much deliberation, however, she came to the conclusion that she would 'return to my home country and be of service to my less privileged sisters'. ${ }^{110}$ She made this decision even though at that point she had not yet been offered a job. Meanwhile, her application for a position to work as a doctor in a leading role at a Travancore hospital had been met with substantial resistance because she was Indian: 'She is not eligible for the Charge of the Women \& Children's Hospital at Trivandrum, as a pure European is required. ${ }^{111}$ Apparently the only argument against this was the fact that no other person with the required qualifications seems to have wanted to take up the position. In a way, Poonen Lukose outdid the potential competition through her excellent London and Dublin degrees. After several letters going to and fro between representatives of different bodies within the British colonial government, Lady Dufferin (who in 1885 established the National Association for Supplying Medical Aid to the Women of India, known as the Lady Dufferin Fund) was called upon to give her advice. She pointed out that 'no English lady Doctor is to be had. But there is a native who seems to be cut out for the post. ${ }^{112}$ Possibly, this remark was the watershed moment in terms of moving the issue forward in internal debates. It seems that Lady Dufferin's intervention, emphasizing Poonen's European qualifications and professional experience, stressed to everyone involved in the process that Poonen was

\footnotetext{
${ }^{109}$ Application and recommendation letters of/for M. C. Poonen, APAC: IOR/L/E/ 7/859.

${ }^{110}$ Poonen Lukose, 'My 86 Years', p. 45.

${ }^{111}$ Internal correspondence between the President of the Medical Board and the Revenue and Statistics Department, 2I January I9I6, APAC: IOR/L/E/7/859.

${ }^{112}$ Lady Dufferin to Sir H. Charles, in February igi6, APAC: IOR/L/E/7/859. On the contradictions between the Fund's goals and its practice on the ground, see S. Lang, 'Colonial Compassion and Political Calculation. The Countess of Dufferin and her Fund', in Contesting Colonial Authority: Medicine and Indigenous Responses in Nineteenth- and Twentieth-Century India, P. Bala (ed.), Lexington Books, Lanham, MD, 2012, pp. 86-99.
} 
the only reasonable choice for the post. Thus, on her second attempt, Poonen was hired as the director of the newly opened Thycaud Women and Children's Hospital. ${ }^{113}$ Surprisingly, she was appointed under the covenant for the employment of Europeans in the state service. ${ }^{114}$ Tickets for passengers to journey across the seas were scarce as all ships were needed in the war effort. Through an acquaintance Poonen was eventually able to secure a place on a boat going to India. Finally, she returned to Thiruvananthapuram at the end of May and began her new job at the beginning of June igi6. From then on her career took off.

More than a century later, in spring 2018, a highly visited news website in Kerala reported the death of a 99-year old, who was apparently the first baby to be brought into the world by Caesarean section at a state hospital in South India. The C-section was performed by a 'guardian angel'Mary Poonen Lukose - and her team of doctors. ${ }^{115}$ In order to convince women in Travancore of the benefits of so-called Western medicine, particularly of giving birth to children in hospital and with respect to paediatrics, Poonen Lukose set an example by delivering both her children in Thycaud Hospital. ${ }^{116}$ Allopathic medicine grew alongside the flourishing practice of local systems of medicine, with the maharaja investing considerably in supporting both vaidyasalas (health clinics) and hospitals that offered treatments in line with Western ideas. ${ }^{117}$ In addition to her role as the director of Thycaud Hospital, Poonen Lukose became durbar physician from 1924, attending to the maharanis of Travancore. Shortly after this, 'she was the first woman to be appointed surgeon-general in an Indian state, at a time when women doctors were still a rarity in Europe and America'. ${ }^{118}$ Her duties as head of the medical department of Travancore included overseeing all hospitals in the state. At her initiative, a tuberculosis

${ }^{113}$ Letter L. J. Kershaw to Lady Dufferin, 5 March igi6, APAC: IOR/L/E/7/859. In the same letter, Kershaw states that the terms and conditions needed to be negotiated between M. Poonen and the Travancore government directly.

${ }^{114}$ Poonen Lukose, 'My 86 Years', p. 46.

115 Anon., 'Kerala's first C-section baby dies at 99', in Manorama online, i May 2018, https://english.manoramaonline.com/news/kerala/2018/o5/II/kerala-first-c-section-babydies.html, [accessed 2 October 2020].

${ }^{116}$ Mary C. Poonen married Kannu Kuzhiyil Kuruvila Lukose in July i917. Madras Mail, I2 July I917, p. 3 .

117 Nagam Aiya, The Travancore State Manual, pp. 544-547.

${ }^{118}$ V. Raman Kutty, 'Historical Analysis of the Development of Health Care Facilities in Kerala State, India', Health Policy and Planning, vol. I5, no. I, 2000, pp. I03-109, p. I04. 
sanatorium was built in Nagercoil and an x-ray and radium therapy institute in Thiruvananthapuram.

Apart from her professional duties, Mary Poonen Lukose actively engaged in political and social work in honorary offices. Her nomination to the Legislative Assembly as the first woman on this body was greeted with enthusiasm by members of the assembly as well as the press. Poonen Lukose stood for the improvement of education for girls and of medical care for women. To further her objectives, she was a member of the YWCA in Thiruvananthapuram. According to her memoir, Poonen Lukose was aware of her position of privilege from an early age. She seems to have been driven by the motivation to improve the situation of women, not only with respect to their health, but also regarding their standing in society. Her sociopolitical activities broadened the boundaries for the indirectly colonized: as a role model for young women who wanted to follow a professional career, Poonen Lukose thus expanded the hitherto unusual to something conceivable.

During the first decades of Mary Poonen Lukose's life, Travancore was a princely state under indirect British rule. It was therefore subject to British colonial regulations with respect to its external policies. This resulted in Travancoreans, among them Poonen Lukose, being classified as British Protected Persons (BPPs). ${ }^{19}$ They had to adhere to British connotations and regulations of citizenship. British citizens were - and to this day are-British subjects; every subject is seen to have a personal relationship to the sovereign (currently the queen) and is thus protected by the state. This notion of a 'citizen' laid the foundation for the idea of an 'imperial citizen'. Up to the First World War, formal citizenship in Great Britain was closely connected to maintaining imperial unity. Ideally, 'imperial citizenship' was to be instituted in order to preserve free movement between all parts of the empire. Considerations around the definition of 'imperial citizenship', however, were not based on the concept of the equality of all citizens before the law, but on categorizing individuals into different types of 'citizen' who were then granted widely diverging privileges and responsibilities. Women - whether in the metropole or in the colonies - were barred from exercising citizenship rights: full suffrage was bestowed on them only in 1928. Across the British empire, significant discrepancies existed between British metropolitan and imperial subjects. According to

${ }^{119}$ For a detailed discussion, see N. G. Jayal, Citizenship and Its Discontents: An Indian History, Harvard University Press, Cambridge, MA, 2013, particularly Chapter I. 
Daniel Gorman, the definition of imperial citizenship at the turn of the nineteenth century might be:

a unified imperial polity in which the individual's allegiance to the sovereign (subjecthood) was of principal importance, and concomitantly sought to maintain and/or develop such allegiance through the encouragement of political liberties, where deemed appropriate, based upon British values of morality and character, for the purpose of creating a cosmopolitan political community. ${ }^{120}$

Importantly, British subjects in the non-Dominion parts of the empire had significantly fewer rights than those in metropolitan Britain and in the Dominions. The differences in status largely emanated from understanding societies as culturally and racially defined as well as the wish to maintain inclusive, homogeneous social in-groups. At the same time, a pan-imperial sentiment across all parts of the empire was emphasized. All attempts to establish an overarching 'imperial citizenship' failed, however, as the Dominions continued to apply their own definitions of formal citizenship which excluded other imperial British subjects, notably British-Indians or, as they were called more generally at the time, 'Asiatic' subjects. British-Indians claimed imperial citizenship, as Sukunya Banerjee shows in her literary analysis of Indian writers' demands for equal citizenship. ${ }^{121}$ On the surface such discriminating legislation was passed for economic grounds, but it was actually for social and 'cultural' reasons. The belief in difference also remained part of the discourse in London. As an imperial status British subjecthood might have conferred (nominal) citizenship, but it did not carry the entitlements and obligations of British metropolitan citizenship. ${ }^{122}$

Arguably, issues of (imperial) citizenship in the British empire were based on a sense of 'Britishness' that carried cultural connotations of being white, Protestant, and morally middle class, and all other values associated therewith. This permeated ideas of (in)equality between individuals across the empire. With respect to citizenship, the most important markers of difference were gender, class, and race. In Britain

${ }^{120}$ D. Gorman, 'Wider and Wider Still? Racial Politics, Intra-Imperial Immigration and the Absence of an Imperial Citizenship in the British Empire', Fournal of Colonialism and Colonial History, vol. 3, 2002, §5.

${ }^{121}$ S. Banerjee, Becoming Imperial Citizens: Indians in the Late-Victorian Empire, Duke University Press, Durham and London, 2010.

${ }^{122}$ Cf. R. Karatani, Defining British Citizenship: Empire, Commonwealth and Modern Britain, Routledge, London, 2003 , p. 192. 
a racialized understanding of the world's population resulted not only in discourses on superiority and inferiority, but led in practice to a hierarchical structuring of the colonial apparatus throughout the British empire. That is, racialized hierarchies became part and parcel of colonial legal administrative structures, where Europeans were perceived to be superior, Asians and Africans inferior. The result was an empire in which (mostly) white English/British governed and others served. ${ }^{123}$ A concrete example is the colonial administration in East Africa, in which the Europeans occupied the highest ranks, Asians could reach the middle ranks, and the lowest ranks were reserved for Africans. In terms of statutory citizenship's rights and privileges, this meant that local inhabitants of British territories could not become fully fledged citizens. They were accorded only the status of BPPs and skin colour remained one of the defining aspects. In practice, then, the promise of equality and freedom of movement of British subjects across the empire did not materialize.

Mary Poonen Lukose felt the discrepancy of the parallel discourse on citizenship which, on the one hand, enabled her to travel and to study on the basis of being a BPP, but, on the other hand, limited her professional career by virtue of her Indian origin. This discrepancy, in Poonen Lukose's case, was overcome only in one instance, and it took a series of letters over the course of several months between high-ranking government officials in both London and Thiruvananthapuram. The correspondence resulted in her being given the directorship of Thycaud Women and Children's Hospital and allowed her to negotiate a European level salary with her employer-something that probably would not have been possible in the Indian presidencies directly ruled by the British. Her salary grade can probably be attributed to the maharani's intention to promote women wherever possible. Poonen Lukose continuously defied norms set for women, for Indians, and for professional and private realms in a colonial context: she obtained degrees in princely and British India, in England and Ireland; took up a position originally reserved for Europeans; engaged in sociopolitical activities for women; and was a member of the Legislative Assembly. In short, she asserted rights for the 'less privileged', particularly for women. As a sociopolitically aware citizen, and despite being denied formal citizenship, she thus increased the latitude for action.

${ }^{123}$ Cf. K. Paul, Whitewashing Britain: Race and Citizenship in the Postwar Era, Cornell University Press, Ithaca, I997, pp. 9, I2-I3. 
In all three imperial contexts discussed here, before the First World War spatial and social mobility was possible. Individuals who had a certain level of education and could afford the journey were able to travel to Europe for training and work. However, in spite of the many qualifications and degrees they attained, their status in British and princely India was not perceived as sufficient when it came to filling coveted high-ranking positions. The introduction of tighter regulations during and after the First World War gradually reduced opportunities, thereby closing avenues to social mobility. Whichever imperial context is investigated, it is noteworthy that citizenship, which is often imagined as a fixed and solidly defined category, is anything but stable. Governments frequently redefine(d) citizenship or recategorize(d) groups of citizens or subjects. The concept of citizenship thus continues to be more fluid than it appears at first sight. Besides this formal or normative, rights-based citizenship, I contend, with Robert Asen, that citizenship needs to be seen as a process and that conceptions of it need to take into account 'fluid, multimodal and quotidian enactments of citizenship in the public sphere'. ${ }^{124}$ The cases of Lisboa, Mariadassou, and Poonen Lukose highlight that they did not allow themselves to be stymied by categories of formal citizenship, sociocultural norms, or racist undertones. Rather, they followed their aspirations for a professional career by perforating the boundaries of colonies and metropoles. They also went beyond the prescribed paths for colonial subjects by broadening their agency in social, cultural, and political realms, at the same time staying within legal requirements and not necessarily complying with the norms set by colonial governments.

\section{Concluding remarks}

This article has illustrated how significant circular intra- and transimperial movements were for aspiring individuals in colonial India across three imperial contexts. At the same time, it has highlighted that physical mobility did not necessarily bring about social mobility. Ensuing discrepancies in terms of being able to move around and between empires and metropoles, while being constrained by hierarchical colonial structures, could result in obscure ambiguities. One such

${ }^{124}$ R. Asen, 'A Discourse Theory of Citizenship', Quarterly Journal of Speech, vol. 9o, no. 2, pp. I89-2II, p. I9I. 
instance was the disregard for Mariadassou's French qualifications, another the employment of Poonen Lukose on Travancore's European salary scale once her appointment had been approved.

The examples presented of medical professionals moving inside, in-between, and across the metropoles and colonies of the Portuguese, French, and British empires as well as princely states of India highlight their comparatively privileged status which allowed them relative freedom of movement in the second half of the nineteenth and the early decades of the twentieth centuries. In stark contrast, later generations encountered numerous restrictions in the form of tighter citizenship regulations, obligatory passports, and visa requirements.

Despite their comparatively elite status, José Camillo Lisboa, Paramananda Mariadassou, Mary Poonen Lukose, and their contemporaries hit the glass ceiling every now and then. At times, degrees were not recognized by a potential higher education institution or employer; at other times, subtle or more overt expressions of racist, sexist, or other discriminating attitudes were evoked. Thus, moving towards a 'better life' remained a huge challenge for medical professionals from the colonies. In the three empires, a bifurcation existed between an idealized equality - expressed in the notion of (imperial) citizenship - and the practised inequality of implementing multilayered citizenship rights for different people. Arguably, the uneven application of citizenship or of being a subject in the Portuguese, French, and British spheres led to the same results for individuals from the colonies, although these were based on different notions and practices of citizenship.

For aspiring individuals on the subcontinent, the recognition of degrees and certificates came to be as crucial for their career paths as questions of citizenship. Perhaps even more decisive were issues of race and origin, which often prevented Indians living in Portuguese, French, or British India from working at an adequate rank and in the locality of their choice. This in turn had an effect on their ability to practise and on their potential social mobility. Thus, I argue that individuals like Lisboa, Mariadassou, and Poonen Lukose had to negotiate parallel discourses: one of citizenship, which enabled them to move around the empire comparatively easily, and a second of tacit sociocultural understandings, which reduced their options of work tremendously by tying them to a hierarchical and regionally based structure put in place by the Portuguese, French, and British colonial governments. Issues of gender, race, class, and caste became manifest, often decisive, for social mobility. Career paths thus were circumscribed through establishing 
barriers of racial and regional origin as well as demands for the 'right' qualifications. As a result, the three doctors discussed here were prevented from entering the higher ranks of the medical services of the colonial governments in India, even though they had the required qualifications. Lisboa and Mariadassou finally opened private clinics in order to practise, and Poonen Lukose was - at her second attempt and exceptionally so-employed in a position that had hitherto been reserved for Europeans. Conceivably, Poonen Lukose's unusual career path was linked to the maharani of Travancore's policies of empowering women in all walks of life. All three expanded imaginations of citizenship and sociocultural norms by creating spaces not only for themselves but also for their colleagues and patients through connecting themselves within a global academic realm, through connecting with local political activists, and through connecting with marginalized groups, especially women, on the spot. In this way, Lisboa, Mariadassou, and Poonen Lukose opened up avenues of possibilities for the colonized on the subcontinent.

Colonial medical professionals, including Lisboa, Mariadassou, and Poonen Lukose, arguably constituted a circulating 'subaltern elite' in the Portuguese, French, and British contexts. Medical personnel, and particularly doctors, played a crucial role in providing healthcare and thus occupied a symbolic position in society. For their work to be successful, they had to inspire the trust of their patients; they held central roles in supplying life and death services that the state had to guarantee; and medical practitioners were usually highly paid and respected. Intra- and transimperial flows of doctors called into question the high status, respect, and trust of the profession as a whole, because doctors from colonies (or today, ex-colonies) were often seen to be 'second-class'. Uncertainties over training standards and language competencies - often with elements of racial prejudice - were (and are) used to defend treating them in discriminatory ways, and migrant doctors found it difficult to find adequate positions in attractive geographical locations - as Paramananda Mariadassou's example, in particular, highlights.

Medical professionals were an elite in some ways, for instance, in that they were comparatively well educated and could work in jobs that were perceived as highly valuable for society. But in other ways, they were also subaltern, for instance, it was often the case that migrant medical personnel faced difficulties in finding adequate employment. In many cases, Indian medics continued to seek better employment opportunities and options - and upward social mobility - elsewhere. In 
a nutshell, medical professionals from the colonies constituted an elite among migrants, but were frequently marginalized among medical doctors. Like other aspiring individuals, they experienced the ambiguities of the parallel discourses of citizenship which allowed them physical mobility across imperial borders on the subcontinent, between the colonies and the metropoles, and between directly and indirectly administered territories, and also regarding notions of gender, race, class, and caste which impaired their careers across three imperial settings. My analysis of the intersections of empire, profession, and citizenship in the nineteenth and twentieth centuries draws our attention to individuals across the many colonial Indias as well as their professional aspirations and sociopolitical activities.

Professionals such as the three examples presented here were, I argue, global citizens circulating within and beyond European empires and their metropoles. Starting with attaining their qualifications and a viable career, Lisboa, Mariadassou and Poonen Lukose had to search out opportunities not easily open to them in any of the imperial environments. They would often be the only Indians on courses and internships. Furthermore, they committed themselves to engage in sociopolitical activities for the greater good, be it through furthering science, striving for the well-being of patients from any social background (in particular, women), and representing local demands and interests in political arenas such as journals, societies, and the legislative assembly. All three affirmed their rights in ways that colonial lawmakers did not necessarily imagine - in either Portuguese, French, British, or princely India - by enacting citizenship in various forms and in multiple ways on a daily basis. Thus, they carved out new spaces and transcended more conventional notions of citizenship linked to statutory rights and responsibilities by crossing physical borders and widening sociocultural boundaries. They lived the lives of global citizens. 